\title{
The Risk of Logistics Outsourcing and Prevention Decision
}

\author{
Yin Hang \\ Eegineeing Training Center \\ Shengyang Aerospace University \\ Shengyang, China \\ yinhang@saue.du.cn
}

\begin{abstract}
Modern enterprise in a period of change and highly uncertain, each enterprise has existed in the management of logistics outsourcing risk, therefore, in the logistics outsourcing management to establish risk awareness, prevent enterprise logistics outsourcing risks as enterprise management an important part of logistics outsourcing.At first, this paper starts with the basic issues of logistics outsourcing means, etc, are introduced in today's society the development of logistics outsourcing, logistics outsourcing are pointed out in the enterprise play an important role. Logistics outsourcing enables enterprises to improve logistics speed, reduce operating costs, optimize organizational structure, improve the core competitiveness, improve the operation of enterprises, flexible, etc. Second, through information to find which expounds the implementation of logistics outsourcing would bring competitive advantage, as well as risks and coping strategies. Because of logistics outsourcing itself is complex, so the enterprise logistics outsourcing itself also has the complexity, thus make the enterprise logistics outsourcing often appeared in the process of interruption, even fail. So although the logistics outsourcing brings to the enterprise a lot of economic benefits, but also bring a lot of risks. Randomness of these risks, mutability and online. I study the purpose of this paper is to make the enterprise logistics outsourcing risk prevention strategy is proposed for logistics outsourcing get benefit maximization.
\end{abstract}

Keywords: Logistics outsourcing; Risk prevention; Coping strategies

\section{INTRODUCTION}

Facing with the fierce market competition, logistics outsourcing has its unique advantages, like increases market reaction ability, improves enterprise's competition in the field of the same industry, so that to reduce logistics operation cost of the enterprise, which are very profitable for future development of the enterprise. More and more Chinese enterprises prefer logistics outsourcing to solve their logistics problem. This paper's research will help to promote actively market, win the competitive advantage with taking logistics outsourcing, so that to push forward a healthy development of the Third Party Logistics(TPL) market of China.Logistics outsourcing is contained in business outsourcing. As an unique logistics outsourcing pattern, it can provide the enterprise with a new logistics resources allocation, and thus boost the development of supply chain, finally enhance enterprise's competitive advantage.

In such a competitive environment, if the enterprises want to gain greater competitive advantages, they should make consideration from the view of enterprise's characteristics, from which they can promote enterprise's competitiveness and maximize the benefits. As the main business of the enterprise, operation experiences of logistics is quite adequate, it also has higher management level. The emergence of TPL can decrease the logistics cost of all the logistics resources, make logistics operation more effectively. Manufacturing enterprises separate their own logistics business, they can focus on mainstream business, giving full play to competitive advantage, which is so-called "logistics outsourcing".

\section{OVERSEAS AND DOMESTIC RESEARCH STATUS}

\section{A. Development Status of Foreign Logistics}

There's rapid changes and development in market economy, struggles between enterprises is more and more serious, linked with personalized demands from the customer's are more and more popular, as well as its pattern is also complicated. The enterprises give a prompt response to market demand and provide customers with a satisfactory service. The more developed countries, the more attention will be paid by the managers on development strategy, which constitutes a part of the enterprise's overall development strategies.

\section{B. Development Status of Domestic Logistics}

Compared with developed countries, logistics level in domestic is lower, and which primarily concentrates on basic level operation: a. Logistics operation efficiency is low, b.Large finished products inventory, c. Inventory and working capital turnover is slow, d. high logistics cost. In a word, there are manydeficiencies exist in our logistics operation process and management pattern. It will take a long time to update and adjust. Facing with this situation, choosing logistics business is an effective measure.

In logistics academic field, the research and development process has a strong hysteresis, so it's difficult for the enterprises to have a complete knowledge about logistics. These enterprises just superficially cognize the logistics as " the third profit source", deep research from enterprise is still absent. From this perspective, logistics development of China not only lags on time, but also has congenitally deficiency. While large number of foreign logistics in developed countries focuses on socialization. In China, many manufacturing enterprises are lack of academic research, and even less on social 
logistics. But from another point of view, at least logistics management has been processed, logistics can reduce operating cost, increase profit, and improve enterprise's competitive capability.

\section{RELATED THEORY INTRODUCTION OF LOGISTICS OUTSSOURCING}

\section{A. Logistics Outsourcing}

\section{1) Related conception of logistics outsourcing}

With the acceleration of global economic integration process and development of application program, in logistics field, logistics outsourcing services will be gradually understood, accepted and used by the social awareness. The so-called logistics outsourcing, that is a TPL company business contract. The manufacturing or sales enterprise entrust the professional TPL to do their logistics business, so that to strengthen core competitiveness, save management cost and realize resources sharing. Outsourcing is a long-term, strategic, mutual penetrative and beneficial business representative and contract execution.

\section{B. The Implementation Steps of Logistics Outsourcing}

Logistics outsourcing has made many enterprises realize that it's a valuable strategy, but at the very beginning, effective planing and coordination are necessary for ensure a smooth transition of outsourcing services. Logistics outsourcing of any company requires carefullyplaning,implementation and management.The following steps can be referred to by the enterpriseswhen they implement logistics outsourcing.

- Should strictly select professional TPL company.

- Have a clear definition for your own expectation.

- To formulateoutsourcing strategy.

- Sign the valid contract.

- Pay attention to potential conflict and solve it on time.

- Execute incentive policy for suppliers.

- To measure performance.

- Develop good specification and process flow.

\section{Risk Theory Introduction of Logistics Outsourcing}

\section{1) The meaning of risk.}

It mainly includes two aspects: one is the nature of risk is uncertain. The other is risk is a kind of objective existence. For the same risk different people may have different opinions. Sum up the conclusions mentioned above, the main points of risk includes:

- Risk refers to an uncertainty loss in a

- particular period;

- Risk means possibility of loss;

- Risk refers to loss occur;

- Risk is a doubt about future situation;

- $\quad$ Risk cannot be predicted, its actual outcome might be barely unsatisfactory;

- $\quad$ Risk refers to measurable uncertainty.

2) The concept of management risk of enterprise logistics outsourcing. It is can be generalized as these 5 points:

- Confirm the risk;

- Identify the risk;
- The appropriate measures to solve risk;

- The implementation of means;

- Evaluation of its effectiveness. How to prevent and control the risk is the essential problem needs to be solved by the enterprise when it faces with risk and loss pressure.

3) The concept elaboration of risk management of enterprise logistics outsourcing.

The objective of risk management for the enterpriselogistics outsourcing is to deal withthe existence of potential risk through a series of management measures, from which it can be defined as: risk management of logistics outsourcing is a special management function, based on possible uncertainty and limitation, through the understanding, measuring, predicting and analyzing to put forward decision-making plan, and expect to obtain a secure maximize or minimum cost, or win the same cost for safer of less loss.

\section{Decision-making Risk of Logistics Outsourcing}

1) Resist risk from employees.

2) Risk of enterprise culture.

3) Cost of the risk.

After the enterprise taking logistics outsourcing, its cost of project is very complicated, such as personnel expenditures, facility cost etc. Because modern logistics management often depends on information processing, so information disposal becomes an essential part involved in cost.

\section{E. The Scope of Outsourcing Risk.}

Modern enterprise logistics outsourcing is the enterprises choose a suitable outsourcing company according to its operation state, scale and business type etc. If inappropriate selection is made, the final achievement or effect might not be obvious, even can cause burden for enterprise, and lead to the failure of outsourcing.

\section{F. Risk Analysis.}

Without a complete planning for the risk, which will leadunreliability of final decision.In a serious circumstance, it can cause mis-operation of the overall logistics outsourcing plan.

\section{THE DEFINITION AND PROPERTY OF LOGISTICS OUTSOURCING RISK}

\section{A. Definition of Logistics Outsourcing Risk.}

There are many views about explanation and stipulation about risk in domestic and foreign academic circle. Normally, the enterprises worry a lot about its future outcome. The occurrence of risk is uncertain, which is also cannot be predicted. However, the consequences of it is veryserious.Uncertainoutsourcing risk during logistics outsourcing can be generalized as follows:

- Risk factor definition of logistics outsourcing. Owning to uncertain factors

like management, market, finance, law and rules during logistics outsourcing,there might have possibility of failure for outsourcing.

- Process definition for implementation of outsourcing. Typically process flowis:analysisof outsourcing 
demand--put forward demanding plan--choose outsourcing supplier--execution of logistics outsourcing--managementoflogistics outsourcing. Once there's problem in each section, the overall logistics outsourcing will be failed.

\section{B. Property of Logistics Outsourcing risk}

\section{1) Abruptness.}

This kind of abruptness is not continuously. It's irregular and out of order,always emerges suddenly.

2) Relevance.

This refers to there's a mutual relationship between the factors.In the enterprise logistic outsourcing, they connect to each other and have closed relationship.

3) Occasionality.

Then enterprise logistics outsourcing has randomness, time and place of risk occurrence and its consequences are all out of control.

\section{PREVENTION MEASURES FOR LOGISTICS OUTSOURCING RISK}

\section{A. Prevention Strategy onExternal Risks ofEnterprise Logistics Outsourcing}

Normally speaking, risk management strategy of logistics outsourcing is divided into controlling risk and financial risk strategy. Here are two main status:

1) Eliminate specific risk unit.

2) Give up some existing risk unit halfway, which is the easiest and also a passive way in risk strategy.

Wether take this strategy is related to final risk losses. Managers need to be aware of threaten from the risk, attention should be paid on many development opportunities lost because of subjective judgment.

Risk undertaken by oneself refers to the enterprise to bear the adverse consequence from risk accident. When trying to change risk occurrence frequency and risk loss, or prevention cost is much higher than loss itself, the enterprise has to take its own risk.

Risk transfer means the enterprise passes the possible logistics outsourcing risk to others. This kind of transfer can be subdivided into insurance transfer and noninsurance transfer.The best example is through logistics outsourcing, the enterprise transfers its own business to the others, thus the possible enterprise outsourcing risk in this business is transferred to the contracted organization. Insurance transfer refers to the enterprise will transfer the risk to insurance company through buying insurance. To reduce the huge uncertainty in business management with small amount of expenditure determined by the finance.

\section{B. Prevention Strategy of Potential Risk of Logistics Outsourcing}

There are following strategies in implementation of logistics outsourcing:

1) Improve the Ability to Identify Enterprise's Core Competitiveness.

This is an important method for improving enterprise strategy. The enterprise should be quite clearly on its capacity to choose a necessary logistics supplier. If implementation of logistics outsourcing is not successful, what other problems can be predicted.

\section{2) Selection of outsourcing partners}

A most important thing in logistics outsourcing is the selection of partner.

\section{3) Manners to control logistics outsourcing.}

Should make supervision for all the process if the enterprise wants to ensure the outsourcing activities go on smoothly. It's necessary to control the practice procedure of the TPL supplier and provide effective information, no matter the enterprise has signed agreement with the TPL suppliers or not.

4) Adjust Internal Organization Structure of the Enterprise.

Should reorganize the internal organization structure, which can make it meet requirements of the TPL company. After reorganization, the two parties can have a better communication and coordination.

\section{Detailed Measures for Preventing Outsourcing risk}

Modern advanced logistics Services Company can provide one-stop,integration and high effective comprehensive services, which brings lots of convenience to the enterprise, as well as can well meet the individual, flexible and high quality services requirement of the enterprise. The development of outsourcing is joyful, but considering the objective existence and uncertainty, it also makeenterprises have lots of concerns and struggles. However, the practicesalso prove that the accident can be prevented, as well as the risk.

Firstly should have a deep analysis about risk prevention, risk management of logistics outsourcing is to analyze possible risk in outsourcing activities. Take varieties of measures to eliminate risk factors, or reduce the danger of risk factors. Analysis and evaluation about logistics outsourcing can help enterprise to take some prevention measurements actively to deal with logistics outsourcing risk through establishing a good risk control and prevention system.

1) Set up internal logistics outsourcing risk management agency

According to its own industrial characteristics, the risk management agency of logistics outsourcing can be organized by enterprise's staff from finance, logistics, information, law supervision department. The scale, project amount and complication of outsourcing services and numbers of logistics suppliers determine the size of risk management agency.

2) Select suitable logistics outsourcing suppliers

Through suitable selection of logistics suppliers and maintenance a good relationship with them, which can reduce all kinds risks of logistics outsourcing.The following related measures should be included:

Select suitable logistics supplier as enterprise's partner;

Appropriate supplier's numbers;

Establish a strategic cooperative partnership.

Design a flexible contract. The principal-agent theory believes that logistics outsourcing is a kind of principalagent relation, in which information asymmetry exist, so that to induce logistics outsourcing risk. 
Set up sharing information support system. Most of the risk in logistics outsourcing risk is information risk. Because many logistics outsourcingis cross-organization, which is involved in multiple enterprises in supply chain. In nowadays, just rely on personnel communication and spreading between suppliers and customers has been unable to adapt to the expansion of logistics outsourcing scope and development status of outsourcing outsourcing levels improving.

Build a co-operation mechanism between enterprises. Logistics outsourcing can reduce enterprise's cost, give a quick reaction to customer's demand.It realizes the advantages like resources sharing, at the same time it also faces great challenge.

Set up risk early waning mechanism. struggles in economic activities is very serious, by risk prediction it can be killed in bud. So that to enhance enterprise's competitiveness, realize a rapid and sustainable development of enterprise.

\section{CONCLUSION}

This paper concentrates on many benefits from implementation of logistics outsourcing for an enterprise, which can win more advantages during market competition. However, logistics outsourcing in currently is not be widely used in our country, and most of the enterprises haven't realized that logistics outsourcing also exist the risk when it brings huge competitive advantages. This is always be neglected by the enterprises, and there has no coping strategy for the risk.

Logistics outsourcing business of our country is still at an early stage, we need to actively introduce better knowledge from foreign countries, research and analyze the successful case, put the theory into practices. In addition, learn to choose the logistics service company with scientific method, strengthen performance management and supervision of logistics suppliers, intensify the cooperation relationship between enterprises and outsourcing suppliers, so that to make our logistics outsourcing business have a better development.

\section{REFERENCES}

[1] Wang Shuyun, Theory and Application of Logistics Outsourcing $\ulcorner\mathrm{M}]$, Peking people's traffic press,2004.34-39.

[2] Tu Haoxian, "Logistics Outsourcing Risk Evaluation Based on Risk Matrix”[J], Logistics Technology,2006(5)66-69.

[3] Shuai Bin, " Critical Effect of Logistics Outsourcing Decisionmaking for Manufacturing Enterprise", Journal of Southwest Jiaotong University, 2006(3)32-37.

[4] Tian Lijuan, "Management and Research about Supply Chian Based on Electronic Business"[J],Finance and Accounting Monthly.2005 (12)89-93.

[5] Bai Xinrong, Su Jingqin,“ Empirical Research of the Causes of Logistics Outsourcing”[J], Science Paper Online, 2005(4)55-59.

[6] Zhu Huamin, "Decision-making Analysis of Logistics Outsourcing”[J],Domestic Transportation, 2006(5)113-116.

[7] Zeng Xiangyun,"Discussion on TPL Operation Risk and Prevention" 「J], China Business and Market,2004(7)17-20.

[8] Liu Xiaoqun, Reason, Risk and Management of Logistics Outsourcing $\left\ulcorner_{\mathrm{J}}\right.$ ], Commercial Economy,2004(4).33-35.

[9] Han Lei, Partner Selection Research of Enterprise Logistics Outsourcing 「D], Shanghai Haishi University:2004.34-37. 